\title{
INDUSTRY 4.0 - "EMPLOYEE 4.0" IN THE LIGHT OF TEACHING AND LEARNING
}

doi: 10.2478/cqpi-2019-0002

Date of submission of the article to the Editor: 03/05/2019

Date of acceptance of the article by the Editor: 24/05/2019

\author{
Anna Wiśniewska-Sałek ${ }^{1}$ - orcid id: 0000-0003-4537-3225 \\ Duangthida Hussadintorn Na Ayutthaya ${ }^{2}$ - orcid id: 0000-0002-1864-2808 \\ Diana Mequita ${ }^{3}$ - orcid id: 0000-0003-3896-6348 \\ Wichai Chattinnawat ${ }^{4}$ - orcid id: 0000-0003-1936-9919 \\ ${ }^{1}$ Czestochowa University of Technology, Faculty of Management, Poland \\ ${ }^{2}$ Asian Institute of Technology, Department of Industrial Systems Engineering (ISE), Thailand \\ 3 University of Minho, Centro Algoritmi (CALG), Portugal \\ ${ }^{4}$ Chiang Mai University, Department of Industrial Engineering, Faculty of Engineering, \\ Thailand
}

\begin{abstract}
Industry 4.0, in the context of revolution, relates to changes in the industry but actually it does not begin or end with it. The most important in the whole process of digitization and intelligent solutions is the human factor. In fact, everything begins with it: design, creation, service and everything ends: implementation, interpretation of results, improvement through previous experiences. Therefore, what should the employee that will meet the challenges of the industrial revolution 4.0 be like? The objective of the paper is to create the profile of the employee 4.0 who, in the education process, uses learning methods and teaching concepts so that they could satisfy the requirements set by the revolutionized economy. The reference point will be the use of the research conducted by the consortium members under the project of MSIE-CBHE, which is Erasmus+ Curriculum Development of Master's Degree Program in Industrial Engineering for Thailand Sustainable Smart Industry (MSIE4.0) funded by the European Commission the authors of the publication also belong to.
\end{abstract}

Keywords: Industry 4.0, MSIE4.0, employee, industrial engineering, knowledge management

\section{INDUSTRY 4.0}

The present times are the times of introducing changes in the economy, the adaptation of production/service solutions to new solutions in terms of Smart Industry (Auer and Langmann, 2019), Industrial Internet of Things (Gilchrist, 2016) or Smart Manufacturing [Moon et al., 2018]. The scientific literature extensively describes the issues of Industry 4.0, analyzing them in terms of many areas and relationships. However, it is doubtful if, in spite of so much research into this subject matter, enterprises are actually prepared for this revolution (Marfleet, 2019; Ślusarczyk, 
2018). It seems that enterprises have access to knowledge which indicates what they should change to operate in the realities of Industry 4.0. However, do they possess knowledge of how to do this or do they possess the human factor prepared for the analysis of data generated using these technologies [Ciancarini et al., 2017; Cuzzuol et al., 2018; Gitelman and Kozhevnikov, 2018; Grenčíková and Vojtovič 2017; Ulewicz and Sethanan, 2019]? The variety of possibilities of the implementation of only the strategy of the fourth industrial revolution in the company indicates that it is indeed the membership of the network of bonds/relationships between its participants (Torna and Vaneker, 2019; Prause and Atari, 2017; Camarinha-Matos et al., 2018). This indicates how extensive this issue is and the binding element seems to be - knowledge. The appropriate substantive preparation of people creating the company (in the form of specific competences) is the basis for learning practical skills, which seems to be a good beginning in terms of implementation of the concept of Industry 4.0 in the company. There is no point in inventing new technologies unless there are people who will understand them.

\section{EMPLOYER 4.0}

The survey questionnaire (Chattinnawat, 2018a) was conducted among 72 entities (22 enterprises were located in Europe - Poland, Romania and Portugal and 50 companies in Asia - Thailand).

The statistical European entrepreneur, included in the survey in 2018, conducts a business activity focused on industrial production with more than 500 employees. The company recorded the turnover of less than EUR 1 million in 2017. The entrepreneur is at the stage of creating the strategy based on the assumptions of Industry 4.0 but does not regularly follow the stages of its creation. In order to increase their competitive position in the market, they consider the Big Data technology (Big data to store and evaluate real-time data) as one of the most important (it is also one of the most desirable skills among employees which has direct impact on improvements in the operation of the company) but currently they are using the technology of embedded IT systems. Over the last two years, the company has moderately invested in production/manufacturing, purchasing, logistics and IT and in the next 5 years it is planning huge investments in production/manufacturing, logistics, sales and service at the level of the average additional investment. The enterprise systematically manages technology and innovation in the area of production technology. From the point of view of the applied business model, the company expresses the opinion that, in order to increase competitiveness (product/service), the level of advancement of Industry 4.0 is significant and should be implemented within 3 years although currently the diversity in the implementation of the business model related to Industry 4.0 is large and difficult to determine. Only $25 \%$ of the assortment amounts to digitized products, which is reflected in the poorly digitized life cycle of the product. In the process of the applied business model, data analysis plays a great role (such data have been monitored for 2-3 years). Cooperation within the supply chain is at the average level but there is no full integration and transparency for customers. The European company declares that the customer is involved in creating the product to the highest degree and in creating the service to the lowest degree. The participation in constructing and thus in the technical process of formation is at an average level both for the product and service. The enterprise, in its assortment, does not possess functional adders based on information and communication technologies. The 
statistical European entrepreneur finds the competences of their employees corresponding to the assumptions of 4.0 - insufficient and the production technology is an area where competence development is the most important. Professional skills, which are at a low level in the case of the existing staff, are the interpretation for the company to create new conditions for them which will increase them. However, newly hired employees are required to highly master these competences (e.g.: IT infrastructure, Automation technology, Data analytics, Data security/communications security, Development or application of assistance systems, Collaboration software, Non-technical skills such as systems thinking and process understanding). The entrepreneur has also limited possibilities in terms of the functionality of equipment infrastructure and direct communication between machinery is impossible. The adaptation of such possibilities itself is irrelevant to them. The selected data, e.g. from optimization of production and logistics processes are obtained directly from machinery in the production process, mostly manually. The most popular systems used by the enterprise are: ERP, PDM, CAD, SCM of which ERP and SCM have interface with the main system. The acquired data are integrated only for the internal level of the company, only the sales department is externally connected with customers or suppliers. In the enterprise, there is no independent operation of production by means of which there is no phenomenon of automatic response to changes in production in real time. The company has the central IT department with the implemented secure solutions in terms of data storage: internal, in the cloud, communication, external and internal with data exchange. The company uses the cloud service with cloud-based software and for data storage without the possibility of their analysis. The vertical value chain is highly digitized (within the last 2 years the ERP system has been integrated) along with the possibility of real-time preview of main processes and changes in their schedule (high degree of digitization of production machinery and equipment). The horizontal value chain integrates logistics functions with poorly related systems offering comprehensive IT solutions. The statistical European entrepreneur provides new services integrated with customer needs, the provision of which is based on the collected data which are analyzed in the course of stages of production and their use. These services amount up to a $20 \%$ share in the company's turnover. Selling products takes place using one channel, i.e. a traditional approach to sales with no access to systems ('offline' sales department). Establishing relationships with customers takes place via proactive communication, information is centralized systematically with a moderate range of cooperation with business partners in terms of exchange of information on customers.

The statistical Thai entrepreneur, according to the most frequently ticked responses in the questionnaire, conducts an industrial production activity. They employ more than 500 people and their turnover in the financial year of 2017 was at the level of EUR 1050 million. Such an entrepreneur is at the stage of creating the strategy of Industry 4.0 whereas they do not conduct the current control of the status of its implementation. However, they believe that the implementation of the assumptions of Industry 4.0 significantly increases competitiveness and they see the need for its implementation within 3 years since, at the moment, this concept refers only partially to different areas of the company's activity. Sensor technologies are technologies which are important to the entrepreneur to increase their competitiveness in the market (nowadays the technology of mobile end devices is the most frequently used). On the other hand, the production technology is an area which the company focuses its attention on in the 
systematic management of technologies and innovation. The company, adapting to the assumptions of Industry 4.0, has invested in the areas of $R+D$, logistics and IT at an average level and in production/manufacturing, purchasing, sales and service to a lesser extent in the last 2 years. The company is planning to additionally invest in all of these areas within the next 5 years at an average level. The company registered in Thailand has digitized products in $25 \%$ with a low degree of digitization of the stages of the product life cycle. For the last 3 years the company has conducted the analysis and monitoring of data believing that it is important from the point of view of the applied business model (the information comes from e.g. customers, it is read from machinery and equipment). However, only $25 \%$ of products/services are customized by customers. The process of their creation takes place with an average degree of collaboration with cooperators. Newly hired employees should have competences corresponding to the requirements they face in terms of the implementation of the assumptions of Industry 4.0. The current situation of the level of knowledge in this field is insufficient for the company to introduce the assumptions of Industry 4.0. However, the company itself declares that it creates the conditions for improving qualifications for employees in relation to technical competences (e.g. production technology, Big data to store and evaluate real-time data). The statistical Thai entrepreneur allows customers to co-design and co-create only the product (this is not possible in the case of services) with no offer in the assortment equipped with functional adders such as: Product memory, Self-reporting, Integration, Localization, Assistance systems, Monitoring, Object information, Automatic identification. Due to the limited possibilities of the functionality of hardware infrastructure, among others, machinery-system, machinery-machinery and interoperability of machinery-system, the adaptation of this infrastructure is irrelevant to the company. The condition of maintenance facilities allows the company for manual collection of only some data during production and the obtained information is used for Quality MGMT. A low degree of digitization causes that ERP, PPS, CM systems are used but they do not have interface with the main system. The data are integrated within internal systems (externally only within logistics). The systems which individually conduct the production process or automatically respond to changes in the conditions of production are not applied. The company has the central IT department, safety is ensured, the data in the cloud are only stored. The value chain, both in terms of vertical and horizontal relations, indicates a low degree of digitization. Therefore, there are no highly advanced and comprehensive solutions enabling e.g. real-time view on all productions with capabilities to dynamically change schedules.

The statistical Thai entrepreneur provides services the utility of which is confirmed by the data acquired (and analyzed) during production stages. The share of such new services amounts to less than $20 \%$ of the whole turnover and a few channels (both digital and non-digital ones) are used for sales. Interaction with customers to communicate messages and send feedback makes use of the approach to sales connected: 'online' with access to relevant systems, e.g. using centrally digitized document. Most of the information acquired from customers is centralized and in an systematic way by single units and is analyzed. Unfortunately, there is no significant cooperation between partners in terms of exchange of data on customers or coordination of marketing activities. 


\section{THE POTENTIAL EMPLOYEE 4.0}

The survey (Chattinnawat, 2018b) was conducted among 540 students (218 respondents studied in Europe - Poland, Romania and Portugal and 322 students in Asia - Thailand). The results of the most frequently ticked responses are presented in Table 1, their interpretation allowed for the presentation of the student's profile in the perspective of the possessed competences of Industry 4.0.

The statistical student of technical masters courses in Europe is a woman and in Asia - a man (although the proportion of women in relation to men is fairly balanced: Europe 50.9\% / 49.1\%; Asia 48.7\% / 51.3\%) with the curriculum defined as "Industrial Engineering". The student has already had some experience of working in the industry. The European experience concentrates on the industry associated with automation and in Asia - on the manufacturing industry. In terms of understanding / defining knowledge/competences relating to the issue of Industry 4.0, the vast majority of students agree that at present (irrespective of the semester they are in) do not have such knowledge. However, they are convinced (to varying degrees) that such skills are necessary to increase their competitiveness in the labor market after they graduate.

Table 1

The most frequent responses of the students from the survey on knowledge and competences concerning the issue of Industry 4.0

\begin{tabular}{|c|c|c|}
\hline & Asia & Europe \\
\hline Level of understanding of ability to define/implement Industry 4.0 strategy & $3^{*}$ & $4^{*}$ \\
\hline \multicolumn{3}{|l|}{ Level of understanding of IT Knowledge and technology with respect to Industry 4.0: } \\
\hline - Sensor technology & 3 & 3 \\
\hline - Mobile devices & 3 & 2 \\
\hline- RFID & 3 & 3 \\
\hline - Realtime Location System & 3 & 2 \\
\hline - Big data technology & 3 & 3 \\
\hline - Cloud technologies as scalable IT infrastructure & 3 & 3 \\
\hline - Embedded IT systems & 3 & 3 \\
\hline - M2M communications & 3 & 2 \\
\hline - Automation Technology & 3 & 2 \\
\hline - CAD/CAM/CAE Technology & 3 & 3 \\
\hline \multicolumn{3}{|l|}{ Level of understanding: } \\
\hline - Computer programming/coding abilities & 3 & 2 \\
\hline - Data and information processing and analytics & 3 & 2 \\
\hline - Data Analytic/Statistical knowledge & 3 & 3 \\
\hline - IT security and data protection & 3 & 2 \\
\hline - Ability to interact with modern interfaces (human-machine/human-robot) & 3 & 2 \\
\hline - Smart Work \& Ergonomics & 3 & 2 \\
\hline - Smart Product & 3 & 3 \\
\hline - Co-created Design & 3 & 2 \\
\hline - Smart Digital Factory & 3 & 2 \\
\hline - Smart operations - Controlling, Adjusting \& Monitoring Process Real Time & 3 & 2 \\
\hline - Data-driven services-Integrated Business and Operational Data & 3 & 2 \\
\hline
\end{tabular}




\begin{tabular}{|l|c|c|}
\multicolumn{1}{|l|}{ Management } & & \\
\hline - Centralized integrative production operation management & 3 & 2 \\
\hline - Digitization life cycle production management & 3 & 2 \\
\hline - Modern Quality Management & 3 & 2 \\
\hline - Modern Supply Chain \& Logistics Management & 3 & 3 \\
\hline - Modern Preventive/Predictive Maintenance Management & 3 & 2 \\
\hline - Modern Business \& Organizational Management for sustainability & 3 & 2 \\
\hline Level of needs to understand: & 4 & 2 \\
\hline - Legal affairs and sustainability & 4 & 4 \\
\hline - Self and time management & 4 & 4 \\
\hline - Adaptability and ability to change in new technologies & 4 & 4 \\
\hline - Team working abilities & 4 & 4 \\
\hline - Social skills & 4 & 4 \\
\hline $\begin{array}{l}\text { - Communication skills } \\
\text { * (somewhat need to learn it in next 2 years); 3 (need to learn it in next 1 years); } 4 \text { (very need to learn } \\
\text { since past 1 years) }\end{array}$
\end{tabular}

Source: (Chattinnawat, 2018b).

The students in Thailand believe that that there is a need (within a year) to extend knowledge of Industry 4.0 and particularly the skill of its adaptation. The statistical student from Europe expresses a slightly different opinion. An overwhelming number of responses indicates that some areas of knowledge or competences in the field of Industry 4.0 should be acquired within 2 years to be competitive in the labor market after graduation. In terms of skills related to providing services based on data through the integration of the product, production and customer, the students from both Europe and Asia believe that competences in the field of time management, group work or social and communications skills are the most important to them now and they should acquire them in the final year. Therefore, it can be concluded that the potential employee, after graduating from technical studies, who will start their professional career in the realities of Industry 4.0 has some requirements as to the acquisition of specific (digitized) technical knowledge. However, they see the need to implement these skills by means of economic interactions (Integrated Business \& Operational Data Management).

\section{CONCLUSION}

The operation in the realities of Industry 4.0 requires the knowledge of this concept, both on the side of the employer and the employee. On the basis of the survey conducted by the team working on 'work packed 1: Gap Analysis' (Lima and Chattinnawat, 2019) under the project of "Curriculum Development of Master's Degree Program in Industrial Engineering for Thailand Sustainable Smart Industry (MSIE4.0)", it can be noted, among both groups of the respondents, that they are not fully prepared for the fourth industrial revolution. The employers do not have the properly prepared strategy compliant with the assumptions of Industry 4.0 and potential employees are not substantively ready for it. The survey results also showed that it does not matter where in the world we do business or learn. The 'profile of the potential employee 4.0' or the 'profile of the employer 4.0' suggested by the authors is very similar both in Thailand, Portugal, Romania or Poland. Slight 
differences in the responses of both entrepreneurs and students have a common denominator - knowledge, and more precisely, its lack. "In order to earn more you need to learn more" - Brain Tracy (Sokołowski, 2012). In the context of this citation, in the current 'economic' times, it is not enough to present knowledge to students. It is also necessary to transfer it through practical utility, which is not a very obvious solution in the case of e.g. science subjects, so necessary to understand the material of engineering studies. Industry 4.0 is a good starting point for changes, also in education. The development in knowledge management should not only amount to what is taught but also or maybe, above all, should concentrate on the ways of its transfer and thus creating new opportunities for learning- interesting and practical.

An example of the approach to teaching through experience is Project Based Learning (PBL). It is a form of situational learning, an active approach to learning. It is important that this method can be arranged in a number of different ways, which makes it flexible in its form. This approach can be defined by means of a few categories: constructive project, research project and training project. PBL can define the general approach to environmental design which will be friendly for active learning. The efficiency of this approach as to the development of transversal skills (Lima et al., 2017; 2015; 2014; van Hattum-Janssen and Mesquita, 2011) is also very important. While facing the results of the conducted survey among students and entrepreneurs under the project co-implemented by the authors, this method allows for creating such a curriculum in the course of engineering studies which will satisfy the needs of both sides in the process of the implementation of the assumptions of Industry 4.0 (Cuzzuol et al., 2018)

The second solution is the 'LOVE' method which is used in the teaching practices at a Thai university (Hussadintorn Na Ayutthaya and Koomsap, 2017). The LOVE model a learning experience model - states that in order to build a strong learning experience contributing to competence development for a particular subject, students must gain four different types of experience: L-learning, O-observing, V-visiting, and E-experimenting (Hussadintorn Na Ayutthaya and Koomsap, 2018; Nitkiewicz et al., 2018; Koomsap et al., 2019). These types of experience are stimulated from a variety of teaching and learning methods (TLs) according to (1.) how students involved in the TLs - passive or active involvement, and (2.) the nature of the learning - absorption to immersion (Hussadintorn $\mathrm{Na}$ Ayutthaya and Koomsap, 2019; Hussadintorn $\mathrm{Na}$ Ayutthaya et al., 2019). Knowledge sharing methods like seminar, lecture, showing video material provide observing experience ( $\mathrm{O}$ : passive absorption) to students. When students are actively involving in the knowledge acquisition process - e.g., involving in a class discussion, accomplishing assignments, preparing for a presentation, participating in a workshop - they are obtaining learning experience $(\mathrm{L}$ : active absorption). Almost existing teaching and learning methods are categorized into this type of experience (Hussadintorn $\mathrm{Na}$ Ayutthaya and Koomsap, 2019). The immersive experience is stimulated when the learning environment is authentic and practical. Field classes and laboratory visits are examples of visiting experience (V: passive immersion). Students are immersed in the practical ambiance and being acknowledged how principles and theories are applied to practice. Experimenting experience ( $\mathrm{E}$ : active immersion) are delivered from laboratory classes, virtual laboratory and simulation, and project-based learning (PjBL). Therefore, in order for students to obtain the LOVE experience to support their competence development, 
teaching and learning methods should be appropriately selected and arranged (Hussadintorn Na Ayutthaya and Koomsap, 2019; Koomsap et al., 2019).

Summing up, it can be concluded that 'education' is the center of sustainable development, both personal and economic. Therefore, it is important for the fourth industrial revolution not to be regarded as exclusively development in the economy (often understood as the application of the latest technologies). It is crucial for it to be present also in the education process, therefore, both the ways of teaching and learning should be changed. Industry 4.0 'expects' the multidimensionality of competences of the employee creating the community in the digited and agile enterprise.

\section{ACKNOWLEDGEMENTS}

This publication is a partial outcome of project "Curriculum Development of Master's Degree Program in Industrial Engineering for Thailand Sustainable Smart Industry (MSIE4.0)" that has been funded with support from the European Commission (Project Number: 586137-EPP-1-2017-1-TH-EPPKA2-CBHE-J8)funded by the

\section{Disclaimer} Erasmus+ Programme of the European Union

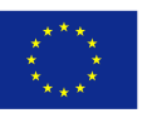

This publication reflects the views only of the authors, and the Commission cannot be held responsible for any use which may be made of the information contained therein.

\section{Reference}

Auer, M.E., Langmann, R. (Eds.), 2019. Smart Industry \& Smart Education. 15th International Conference on Remote Engineering and Virtual Instrumentation, Duesseldorf, Germany, Springer International Publishing, Proceedings.

Camarinha-Matos, L.M., Afsarmanesh, H., Rezgui, Y. (Eds.), 2018. Collaborative Networks of Cognitive Systems. 19th IFIP WG 5.5 Working Conference on Virtual Enterprises, PRO-VE 2018 Cardiff, UK, Proceedings, Springer, IFIP International Federation for Information Processing, DOI: 10.1007/978-3-319-99127-6

Chattinnawat, W., 2018a. Work Package 1: Task 1.3 Industrial Questionnaire Analysis (Thai+Eu Company). Curriculum Development of Master's Degree Program in Industrial Engineering for Thailand Sustainable Smart Industry. Available at: https://msie4.ait.ac.th/category/gallery/reports/

Chattinnawat, W., 2018b. Work Package 1: TASK 1.3 Student Questionnaire Analysis (Thai+Eu Student). Curriculum Development of Master's Degree Program in Industrial Engineering for Thailand Sustainable Smart Industry. Available at: https://msie4.ait.ac.th/category/gallery/reports/

Ciancarini, P., Poggi, F., Horridge, M., Zhao, J., Groza, T., Suarez-Figueroa, M.C., d'Aquin, M., Presutti, V. (Eds.), 2017. Knowledge Engineering and Knowledge Management. EKAW 2016 Satellite Events, EKM and Drift-an-LOD Bologna, Italy, Springer International Publishing AG.

Cuzzuol, G.D., Campos, L.B.P., Mesquita, D., Lima, R.M., 2018. Engineering Students Can Use the Words "Calculus" and "Love" in the Same Sentence: Using Active Learning the Impossible Can Happen. 10th International Symposium on Project Approaches in Engineering Education (PAEE) and 15th Active Learning in Engineering Education Workshop (ALE) Brazil, 273-281. 
Gilchrist, A., 2016. Industry 4.0: The Industrial Internet of Things. Apress Media, Springer Science+Business Media New York.

Gitelman, L.D., Kozhevnikov M.V., 2018. Paradigm of Managerial Education for a Technological Breakthrough in the Economy, Экономика Региона, 14(2), 433-449, DOI: 10.17059/2018-2-8

Grenčíková, A., Vojtovič, S., 2017. Relationship of generations $X, Y, Z$ with new communication technologies. Problems and Perspectives in Management, 15(2-3), 557-563, DOI: 10.21511/ppm.15(si).2017.09

Hussadintorn Na Ayutthaya, D., Koomsap, P., 2017. Assessment of Student Learning Experience with 'LOVE'. 11th International Technology, Education and Development Conference, INTED2017, Valencia, Spain. Proceedings, DOI: 10.21125/inted.2017.0588

Hussadintorn Na Ayutthaya, D., Koomsap, P., 2018. An Application of 'LOVE' Model for Assessing Research Experience. 25th ISTE International Conference on Transdisciplinary Engineering, Modena, Italy. Proceedings, DOI: 10.3233/978-161499-898-3-712

Hussadintorn Na Ayutthaya, D., Koomsap, P. 2019. LOVE-Based Teaching and Learning Method Classification. 13th International Technology, Education and Development Conference, INTED2019, Valencia, Spain. Proceedings, DOI: 10.21125/inted.2019.0914

Hussadintorn Na Ayutthaya, D., Koomsap, P., Lima, R.M., Nitkiewicz, T., 2019. Learning Experience from Teaching and Learning Methods in Engineering Education: Instructors' Viewpoint. 13th International Technology, Education and Development Conference, INTED2019, Valencia, Spain. Proceedings, DOI: 10.21125/inted.2019.0919

Koomsap, P., Hussadintorn Na Ayutthaya, D., Nitkiewicz, T., Lima, R.M., Luong, H.T., 2019. Course Design and Development: Focus on Student Learning Experience. 11th International Symposium on Project Approaches in Engineering Education/ 16th Active Learning in Engineering Education Workshop, PAEE/ALE 2019, Hammamet,Tunisia.

Lima, R.I., Chattinnawat, W., 2019. Work Package 1 -Gap Analysis: Outcome 1.4 Analysis of needs of industry and students. Curriculum Development of Master's Degree Program in Industrial Engineering for Thailand Sustainable Smart Industry. Available at: https://msie4.ait.ac.th/category/gallery/reports/

Lima, R.M., Mesquita, D., Fernandes, S., Marinho-Araújo, C., Rabelo, M., 2015. Modelling the Assessment of Transversal Competences in Project Based Learning. 5th International Research Symposium on PBL, [in] International Joint Conference on the Learner in Engineering Education (IJCLEE 2015), Aalborg University Press, 12-23.

Lima, R.M., Mesquita, D., Flores, M.A., 2014. Project Approaches in Interaction with Industry for the Development of Professional Competences. Industrial and Systems Engineering Research Conference (ISERC 2014), Montréal, Canada.

Lima, R.M., Mesquita, D., Rocha, C., Rabelo, M., 2017. Defining the Industrial and Engineering Management Professional Profile: a longitudinal study based on job advertisements. Production, 27(spe), e20162299, DOI: 10.1590/0103-6513.229916

Marfleet, F., 2019. Zukunftsvision: Sind Sie reif für Industrie 4.0? Finanzquellen ausschöpfen und zukünftige Geschäftsmöglichkeiten schaffen, Expense Reduction Analysts Mittelstands studie. 
Moon, I., Gyu, Lee G.M., Park, J., Kiritsis, G., von Cieminski, G. (Eds.), 2018. Advances in Production Management Systems. Smart Manufacturing for Industry 4.0. IFIP WG 5.7 International Conference, APMS 2018 Seoul, Korea, Proceedings, Part II.

Nitkiewicz, T., Hussadintorn Na Ayutthaya, D., Koomsap, P., Chattinnawat, W., 2018. The Quality of Education on Workplace Safety Master Studies -The Issue of Teaching Methods, CzOTO 2019, 1(1), 661-669, DOI: https://doi.org/10.2478/czoto-2019-0084

Pine, B.J., Gilmore, J.H., 1998. Welcome to the experience economy, Harvard business review, 76, 97-105.

Prause, G., Atari, S., 2017. On sustainable production networks for Industry 4.0, Entrepreneurship and Sustainability, 4(4), 421-431, DOI: 10.9770/jesi.2017.4.4(2)

Ślusarczyk, B., 2018. Industry 4.0 - are we Ready? Polish Journal of Management Studies, 17(1), 232-248, DOI: 10.17512/pjms.2018.17.1.19

Sokołowski, D., 2012. Giełda, pasja, pieniądze! Wyd. "Złote Myśli".

Torna, I.A.R., Vaneker, T.H.J., 2019. Mass Personalization with Industry 4.0 by SMEs: a Concept for Collaborative Networks. International Conference on Changeable, Agile, Reconfigurable and Virtual Production, Procedia Manufacturing 28, 135-141, DOI: 10.1016/j.promfg.2018.12.022

Ulewicz, R., Sethanan, K., 2019. Quality of Educational Services - Industry 4.0 Requirements. Kvaliteta Obrazovnih Usluga - Zahtjevi 4.0 Industrije, 20. međunarodni simpozij o kvaliteti/20th International Symposium on Quality Kvaliteta - Jučer, Danas, Sutra/Quality - Yesterday, Today, Tomorrow Pula, Hrvatska, Pula, Croatia, 137-149, DOI: 10.11222/020.01.011.19

van Hattum-Janssen, N., Mesquita, D., 2011. Teacher perception of professional skills in a project-led engineering semester. European Journal of Engineering Education, 36(5), 461-472, DOI:10.1080/03043797.2013.833170 